\title{
Hormone Research
}

Achondroplasia 60, 65

Adiponectin 56

Androgens 35

Apoptosis 60

Aromatase inhibitors 35

Astroglial cells 15

Bisphosphonates 77

Body proportion 65

Bone growth 71

- mass 71

- mineral density 77,80

Brain repair 1

Breast cancer 50

Calcium absorption 71

Cardiovascular disease 136

Chronic illness 35

Congenital hypothyroidism 96

Conjugated oestrogens 35

Constitutional delay of growth and puberty 35

Culture 11

Delayed puberty 35

Differentiation 1

Disrupters 49

Dominant negative 51

Embryonic stem cells 11

Environmental exposures 50

- influence 49

Ethinyloestradiol 35

Etiology 50

Fibroblast growth factor receptor 360

Final height 113

Follicle stimulating hormone 21

- _ - receptor 21

Fracture 77

Functional genomics 103

G protein 87

Gene cloning 96

Gene-disrupted mice 103

Genetic manipulation 11

Genomics 103

Glial-neuronal communication 15

Glucocorticoids 77
Glucose metabolism 113

Gonadotropin releasing hormone 21

- - - receptor 21

Gonadotropins 35

Growth 65

- factors 15

- hormone 65, 103, 113

- - antagonists 103

- - deficiency 80

- receptor 103

- velocity 124

Hormones 50

Human milk 71

- stem cells 11

Hypogonadism 21, 35

Hypothalamus 15

IGF 115

IGFBP 115

IGFBP-3 115

IGF-I 115,136

IGF-II 115

Imprinting 87

Infertility 21,49

Insulin resistance 51,56

- secretion 131

- sensitivity 131

Insulin-like growth factor binding protein-1 phosphorylation 124

- _ _ p proteins 131

- - factor-I 60

- - factors 131

Insulin-producing $\beta$-cells 10

Iodide recycling 96

Islet transplantation 10

IUGR 115,136

Knemometry 124

Luteinizing hormone 21

- - receptor 21

Male reproduction 49

Mutation 21

Neonatal 124

Neural stem cells 1
Newborn 124

Nuclear receptor 51

Oestrogens 35

Onset of puberty 15

Osteoporosis 77

Oxandrolone 35

Parathyroid hormone-related peptide 60

Partial lipodystrophy 51

Peak bone mass 80

Peroxisome proliferator-activated receptor- $\gamma 51$

Pesticides 50

Placental GH 136

PPPIR3 51

Precocious puberty 21, 31

Preterm infant 124

Programming 124

Proteomics 103

Pseudohypoparathyroidism 87

Pubarche 31

Puberty 31,35

Regeneration 1

Rejection 11

Repair 11

Serial analysis of gene expression 96

Sex steroids 35

Sexual development 15

SGA 113,115

Size at birth 131

Skeletal dysplasia 65

Specification 1

Testicular cancer 49

Testosterone 35

Thelarche 31

THOX proteins 96

Thyroid 96

Transgenic mice 103

Transplantation 11

Treatment 31

Type 2 diabetes 131

Visceral fat 56

\section{KARGER}

(c) 2003 S. Karger AG, Base

Fax +4161306 1234

E-Mail karger@karger.ch

www.karger.com

Accessible online at: www. karger.com/hre 